\title{
COGONGRASS ROOT EXTRACT FROM FIVE DIFFERENT SOILS TYPES FOR SUPPRESSING PURPLE BLOTCH AND INCREASING GROWTH AND YIELD OF SHALLOTS
}

\author{
Rokhlani $^{1}$, Loekas Soesanto ${ }^{2}$, Subandi Nur ${ }^{3}, \&$ Nur Prihatiningsih ${ }^{2}$ \\ ${ }^{1}$ Postgraduate Master of Agronomy, Faculty of Agriculture, Jenderal Soedirman University, Indonesia \\ ${ }^{2}$ Faculty of Agriculture, Jenderal Soedirman University, Indonesia \\ Jl. Dr. Soeparno 73 Purwokerto 53123 \\ ${ }^{3}$ Faculty of Agriculture, Swadaya Gunung Jati University, Indonesia \\ Jl. Pemuda No. 30 Cirebon 45132 \\ E-mail: lukassusanto26@gmail.com
}

Manuscript received: 17 August 2019. Revision accepted: 18 May 2021.

\begin{abstract}
Cogongrass root extract from five different soils types for suppressing purple blotch and increasing growth and yield of shallots. The aim of this study was to examine the efficacy of cogongrass (Imperata cylindrica (L.) Beauv.) root extracts from five different soil types (Typic Udipsamments, Aeric Endoaqualfs (=Gleisal Eutrik), Typic Quartzipsamments (=Regosol Eutrik), Aquertic Chromic Hapludalfs, and Pachic Hapludolls) in suppressing purple blotch and increasing growth and yield of shallots. Split plot design was used with 13 treatments repeated three times, and 18 plants plot $^{-1}$. The treatments consisted of control, fungicide propineb applied before and after inoculation, and five types of cogongrass root extract 50,60, and 70\% concentration applied before and after inoculation. Results showed that cogongrass root extract collected from Pachic Hapludolls which was applied before inoculation had significant effect on the highest pathosystem component indicated by delaying the incubation period, suppressing the intensity of the disease, slowing down the infection rate, and decreasing values of AUDPC as $41.85,69.87,75.13$, and $67.63 \%$, respectively, compared to control. The cogongrass root extract from Pachic Hapludolls applied before inoculation could increase plant fresh and dry weight plant ${ }^{-1}$, tuber weight plant ${ }^{-1}$, plant fresh and dry weight plot ${ }^{-1}$, and tuber dry weight plot ${ }^{-1}$ as $42.7,49.6,51.92,66.75,72.29$, and $73.53 \%$, respectively, compared to control.
\end{abstract}

Key words: cogongrass roots extract, growth and yield, purple blotch, shallot

\section{INTRODUCTION}

Purple blotch caused by Alternaria porri (Ellis) Cif. is a disease in shallots that is very damaging and causes significant yield loss (Dar et al., 2020). Purple blotch was reported to cause a decrease in shallot production by up to $97 \%$ in onion fields worldwide (Kareem et al., 2012).

Efforts to control the disease are still emphasized on the use of synthetic chemical fungicides, in that their continuous use has a negative impact on the environment, the emergence of new strains and also damages human health (Idris \& Nurmansyah, 2015; Sari et al., 2016). Therefore, it is necessary to reduce the use of the chemical fungicides. One of them is the use of botanical fungicides that are safe and environmentally friendly.

Many plants can be used as botanical fungicides including cogongrass (Imperata cylindrica) (Gusmarini et al., 2014). Cogongrass contains alkaloids, flavonoids, steroids, terpenoids, and tannins which have antimicrobial effects and are a form of plant defense mechanism against pathogenic microbes (Seniwaty et al., 2009; Gurjar et al., 2012). Cogongrass can be found in a variety of habitats and a variety of soil types from natural areas that are relatively undisturbed and tolerant of a variety of growing conditions including shade, drought, and poor soil quality (Bryson et al., 2010). The role of chemical compounds produced by cogongrass depends on the soil-plant system (Mallik, 2000). This study aimed to test the efficacy of cogongrass root extract from five different soil types to suppress purple blotch, increase growth and yield of shallots.

\section{MATERIALS AND METHODS}

Research Site. This research was carried out at the Laboratory of Plant Protection, Faculty of Agriculture, and Integrated Laboratory, Jenderal Soedirman 
University, and Agricultural Clinic of the Agriculture and Food Security Service at Tegal Regency and on the land of Sidapurna Village, Dukuhturi, Tegal (-6053'32“, 10905'36", 24 m above sea level, with soil type Aeric Endoaqualfs (=Gleisal Eutrik), from August 2018 to June 2019.

Experimental Design. The in vitro experiment used a completely randomized design with 18 treatments and 3 replicates, consisted of a comparative fungicide (propineb) and cogongrass root extract treatment from five types of soil, namely Typic Udipsamments, Aeric Endoaqualfs, Typic Quartzipsamments (=Regosol Eutrik), Aquertic Chromic Hapludalfs, and Pachic Hapludolls. The in vivo experiment used a split plot design consisted of 13 treatments, 3 replicates, and 18 plants per plot. The main plot was the application time, namely before and after inoculation. Subplot was the treatment of cogongrass root extract from five types of soil. Cogongrass sampling technique was cluster random sampling (Taherdoost, 2016).

Preparation of Cogongrass Root Extract. The development of cogongrass extract began with preparing simplicia according to the method of Ahmad et al. (2014), followed by extraction with the $96 \%$ ethanol maceration method (Zhang et al., 2018). Furthermore, the filtrate was concentrated with a rotary evaporator at a temperature of $30-40{ }^{\circ} \mathrm{C}$ (Muchtaromah et al., 2018), resulting in a concentrated total extract. Determination of flavonoid levels was carried out by comparing quercetin (Chandra et al., 2014).

Preparation of the Pathogen Suspension. Pathogenic fungus $A$. porri was propagated using sterile potato dextrose broth (PDB) aseptically. The culture was shaken with a shaking machine (VRN-200) for 10 days at medium speed at room temperature and ready for use (Abdel-Hafez et al., 2013). Meanwhile, suspension of $A$. porr $i$ was prepared by adding $900 \mathrm{~mL}$ of distilled water to the erlenmeyer containing $100 \mathrm{~mL}$ of pure culture).

Preparation of Shallot Seeds. The shallot seeds used were certified onion seeds of the Bima Brebes variety from Pokar Suka Tani, Sidapurna Village, Dukuhturi District, Tegal Regency. The seed tubers used were medium sized tubers $(5-10 \mathrm{~g})$. The appearance of seed tubers must be healthy, well-pithy (dense, not wrinkled), and bright in color (not dull), the shelf life of seeds was 3 months (Sumarni et al., 2012).
Preparation of Land. The soil was processed until it was loose, then the beds were made with a length of $13 \mathrm{~m}, 1.20 \mathrm{~m}$ wide, $0.5 \mathrm{~m}$ gutter width with $0.6 \mathrm{~m}$ gutter depth. The plot size of each treatment was $70 \times 30 \mathrm{~cm}$ (adjusting the land condition). Basic fertilizer was given before the last hoeing ( 7 days before planting), namely using NPK Mutiara fertilizer (16:16:16) $500 \mathrm{~kg} \mathrm{ha}^{-1}$, SP-36 $100 \mathrm{~kg} \mathrm{ha}^{-1}, \mathrm{KCl} 60 \mathrm{~kg} \mathrm{ha}^{-1}$ by spreading over the beds then stirring land (according to farmer's habits).

Planting and Fertilization. Seed tubers were planted at a spacing of $15 \times 15 \mathrm{~cm}$ with a stick, the holes were made as deep as the average tuber. The shallot bulb was inserted into the hole in the plant using a screwlike motion, so that the tip of the bulb appears flat with the soil surface. The seeds were not planted too deep. After planting, the entire land was watered with a fine grain. The first follow-up fertilization in the form of $\mathrm{N}$ and $\mathrm{K}$ fertilizers was carried out at the age of 10 days after planting (DAP) and the second at the age of 30 DAP, 0.5 doses each. The dose of $\mathrm{N}$ fertilizer was $200 \mathrm{~kg} \mathrm{ha}^{-1}$ and the dose of $\mathrm{K}$ fertilizer was $100 \mathrm{~kg} \mathrm{ha}^{-1}$ (Sumarni et al., 2012).

Fungal Pathogen Inoculation. Shallot plants were inoculated by spraying $A$. porri conidia suspension with a density of $1 \times 10^{6}$ conidia $\mathrm{mL}^{-1}$ of water when the shallot plants were 3 weeks after planting (WAP) (Marlitasari et al., 2016). Each plant was sprayed with $5 \mathrm{~mL}$ of the suspension (Rai \& Singh, 1980). Spraying the suspension was carried out at 05.30 PM. Furthermore, it was closed with a polyethylene lid for 48 hours to maintain high humidity, after 48 hours the lid was opened and the plants were left in normal conditions (Marlitasari et al., 2016).

Plant Maintenance. Watering was carried out to rinse the leaves of the plant, namely to reduce the soil splash that sticks to the shallots. Maintenance of shallot plants was also carried out by controlling weeds by manually weeding. Meanwhile, to control pests, a bioinsecticide was used, namely Bio B10 with the active ingredient Beauveria bassiana secondary metabolites. The concentration used was $10 \mathrm{~mL} \mathrm{~L}^{-1}$ at intervals of 3 days (based on farmer habits).

In Vivo Test. Cogongrass root extract was treated twice, namely before inoculation (S1) and after inoculation (S2). The extract application before inoculation was carried out 3 times, namely when the plants were 10, 15, and 20 DAP. The first application 
after inoculation was carried out 24 hours after inoculation and an interval of 5 days after the first application (Jhala et al., 2017), namely 22, 27, 32 DAP. The dose used was $5 \mathrm{~mL}^{\text {plant }}{ }^{-1}$ (Tombe et al., 2012).

Observed Variables. The inhibitory ability test was carried out by the disc diffusion method (Liu et al., 2016). The disc method was carried out using disc paper with a diameter of $6 \mathrm{~mm}$. The antifungal activity was determined by the formula (Suryanto et al., 2011):

$$
\mathrm{I}=\frac{\mathrm{r}_{1}-\mathrm{r}_{2}}{\mathrm{r}_{1}} \times 100 \%
$$

$\mathrm{I}=$ the level of cogongrass root extract inhibition,

$\mathrm{r}_{1}=$ trace pathogenic colonies to the Petri dish,

$r_{2}=$ trace pathogenic colonies leading to disc paper.

The level of inhibition was calculated by the equation of Bekker et al. (2006), namely:

$$
\mathrm{r}=\mathrm{y}-\mathrm{x}
$$

$\mathrm{r}=$ inhibition zone,

$\mathrm{x}=$ fungal colony radius which has stunted growth (mm),

$\mathrm{y}=$ radius of fungal colony with normal growth (mm).

The method of measuring the dry colony weight of $A$. porri was by preparing pathogenic fungi from the 6 days inhibitory test results, adding $10 \mathrm{~mL}$ of $1 \% \mathrm{HCl}$ to each Petri dish and heating it in a water bath until it melts, pouring it on filter paper with known weight, spraying it with sterile water, and the remaining colonies on filter paper were dried in an incubator at $30{ }^{\circ} \mathrm{C}$ for 24 hours, then weighed twice (Supriyanto et al., 2020).

Observation of the incubation period was carried out every day from the time the plants were inoculated until the time symptoms appeared. Disease intensity was recorded 10 day after inoculation (DAI) (Jhala et al., 2017), namely when the plants were $33,36,39,42,45$, and 48 DAP and calculated by the formula:

$$
\mathrm{DI}=\frac{\sum(\mathrm{n} \times \mathrm{v})}{\mathrm{N} \times \mathrm{Z}} \times 100 \%
$$

$\mathrm{DI}=$ disease intensity $(\%)$,

$\mathrm{n}=$ number of plant parts affected (strands),

$\mathrm{v}=$ damage scale value,

$\mathrm{N}=$ number of leaves observed,

$\mathrm{Z}=$ the highest scale. The value of the damage scale according to Abdel-Hafez et al. (2013) were 0 (no symptoms), 1 (1-25\% infected leaves), 2 (26-50\% infected leaves), 3 (51-75\% infected leaves), and 4 (76-100 infected leaves).
Area Under Disease Progress Curve (AUDPC) was caldulated by a formula of Ling et al. (2017) as followed:

$$
\operatorname{AUDPC}=\sum_{i}^{n-1}\left(\frac{y_{i}+y_{i+1}}{2}\right)\left(t_{i+1}-t_{i}\right)
$$

$\mathrm{y}_{\mathrm{i}}=$ disease severity on the $\mathrm{i}$ th date;

$\mathrm{t}_{\mathrm{i}}=\mathrm{i}$ th day;

$\mathrm{n}=$ number of dates on which purple Blotch was recorded

The infection rate was calculated using epidemiological formula of Van Der Plank (1963):

$$
\mathrm{r}=\frac{2.3}{\mathrm{t}}\left(\log \frac{\mathrm{x}_{\mathrm{t}}}{1-\mathrm{x}_{\mathrm{t}}}-\log \frac{\mathrm{x}_{\mathrm{o}}}{1-\mathrm{x}_{\mathrm{o}}}\right)
$$

$\mathrm{r}=$ infection rate,

$\mathrm{t}=$ interval of observation time,

$\mathrm{xt}=$ proportion of sick leaves at time $\mathrm{t}$,

xо $=$ proportion of sick leaves at the beginning of observation. The units used were units per day.

Observations of plant height, number of leaves, number of tillers were carried out on 10 sample plants per experimental plot which were determined systematically with a U pattern (Setiawati et al., 2011), and starting at 7, 14, 21, 28, and 35 DAP. Leaf chlorophyll was measured using SPAD at the end of the vegetative phase of the plant, while yield component observations were measured after harvest. Leaf area measurements were carried out when the plants were 35 DAP with the cylinder method (Maftuchah \& Idiyah, 1995).

$$
\mathrm{LD}=\left(2 \cdot \pi \cdot \mathrm{r}_{1} \cdot \mathrm{h}_{1}\right)+\left(1 / 3 \cdot 2 \cdot \pi \cdot \mathrm{r}_{2} \cdot \mathrm{h}_{2}\right)
$$

$\mathrm{r}_{1}=$ radius of tube,

$\mathrm{h}_{1}=$ height of tube,

$\mathrm{r}_{2}=$ radius of cone,

$\mathrm{h}_{2}=$ cone height.

The total phenol content of leeks was measured by the Folin-Ciocalteu method from Blainski et al. (2013) modified.

Data Analysis. Data analysis of variance was carried out, if there was a significant difference in treatment, the DMRT test was carried out at the 5\% level. 


\section{RESULTS AND DISCUSSION}

Based on the results of the analysis, the treatment of cogongrass root extract from five types of soil gave differences to the growth of $A$. porri (Table 1). Treatment of root extract $60 \%$ collected from Pachic Hapludolls gave the better results compared to Aeric Endoaqualfs cogongrass root extract and was not significantly different from other treatments, including the comparator propineb fungicide, in inhibiting the development of $A$. porri colonies, with an inhibition of $55.80 \%$.

This showed that almost all extracts had the same potential to suppress the growth of $A$. porri in in vitro tests. The chemical compounds produced by cogongrass roots were thought to be different in each type of soil, so that they had a different effect on microbes. Soil allelopathy is influenced by soil conditions, growing conditions of giver and recipient plants, and climatic conditions. Soil factors that influence are soil texture, organic and inorganic materials, moisture and organisms that affect phytotoxin activity in the soil (Kobayashi, 2004).
The lowest percentage of inhibition was found in the treatment of Aeric Endoaqualfs cogongrass root extract $60 \%$ and it was not significantly different from all treatments, apart from the treatment of Pachic Hapludolls cogongrass root extract at 50 and $60 \%$ of consentration and Typic Quartzipsamments all concentrations. Propineb fungicide treatment at all concentrations was not different from almost all cogongrass root extract treatments. Based on the results of the analysis above, it appeared that the two observed variables were interrelated. The large inhibition zone value and inhibition percentage tended to cause the small dry weight of $A$. porri colonies on PDA, the smaller the inhibition zone and the percentage of inhibition, the colony dry weight tended to be greater. This showed that the cogongrass root extract could replace the role of propionebic function.

The real effect of cogongrass root extract was possible because of the presence of flavonoid compounds. The cogongrass root extract of Pachic Hapludolls contains flavonoids $420.861 \mathrm{mg} \mathrm{L}^{-1}$ followed by cogongrass root extract of Aquertic Chromic Hapludalfs (369.846 $\left.\mathrm{mg}^{-1}\right)$, of Typic

Table 1. Effect of soil type where it was grown and when the cogongrass root extract was applied to the growth of A. porri colonies in vitro

\begin{tabular}{lcccc}
\hline $\begin{array}{c}\text { Types of soil where } \\
\text { cogongrass grow }\end{array}$ & $\begin{array}{c}\text { Consentration } \\
(\%)\end{array}$ & $\begin{array}{c}\text { Inhibition zone } \\
(\mathrm{cm})\end{array}$ & $\begin{array}{c}\text { Colony dry weight } \\
(\mathrm{mg})\end{array}$ & $\begin{array}{c}\text { Inhibition } \\
(\%)\end{array}$ \\
\hline Comparison (propineb) & 50 & $1.97 \mathrm{abc}$ & $26.33 \mathrm{ab}$ & $54.28 \mathrm{c}$ \\
& 60 & $1.70 \mathrm{abc}$ & $18.33 \mathrm{a}$ & $46.09 \mathrm{abc}$ \\
& 70 & $1.97 \mathrm{abc}$ & $18.67 \mathrm{a}$ & $54.11 \mathrm{c}$ \\
Typic Udipsamments & 50 & $1.93 \mathrm{abc}$ & $25.00 \mathrm{ab}$ & $48.67 \mathrm{bc}$ \\
& 60 & $2.07 \mathrm{abc}$ & $20.00 \mathrm{a}$ & $52.12 \mathrm{c}$ \\
Aeric Endoaqualfs & 70 & $2.07 \mathrm{abc}$ & $25.00 \mathrm{ab}$ & $51.56 \mathrm{c}$ \\
& 50 & $1.00 \mathrm{a}$ & $25.67 \mathrm{ab}$ & $34.13 \mathrm{ab}$ \\
Typic Quartzipsamments & 60 & $0.93 \mathrm{a}$ & $19.33 \mathrm{a}$ & $30.53 \mathrm{a}$ \\
& 70 & $1.00 \mathrm{a}$ & $25.00 \mathrm{ab}$ & $33.68 \mathrm{ab}$ \\
Aquertic Chromic Hapludalfs & 50 & $2.03 \mathrm{bc}$ & $33.33 \mathrm{~b}$ & $54.83 \mathrm{c}$ \\
& 60 & $1.92 \mathrm{bc}$ & $19.00 \mathrm{a}$ & $51.82 \mathrm{c}$ \\
& 70 & $1.98 \mathrm{bc}$ & $21.67 \mathrm{a}$ & $53.72 \mathrm{c}$ \\
Pachic Hapludolls & 60 & $1.43 \mathrm{abc}$ & $23.33 \mathrm{a}$ & $46.63 \mathrm{abc}$ \\
& 70 & $1.43 \mathrm{abc}$ & $21.67 \mathrm{a}$ & $46.30 \mathrm{abc}$ \\
& 50 & $1.43 \mathrm{abc}$ & $18.33 \mathrm{a}$ & $46.09 \mathrm{abc}$ \\
& 60 & $1.83 \mathrm{bc}$ & $20.33 \mathrm{a}$ & $48.27 \mathrm{bc}$ \\
& 70 & $2.10 \mathrm{c}$ & $19.33 \mathrm{a}$ & $55.80 \mathrm{c}$ \\
\hline
\end{tabular}

The numbers followed by the same letter in the same column are not significantly different according to the DMRT level of $5 \%$. 
Quartzipsamments (333.845 $\mathrm{mg} \mathrm{L}^{-1}$ ), of Aeric Endoaqualfs (290.461 $\left.\mathrm{mg} \mathrm{L}^{-1}\right)$, and the lowest was the root extract of Typic Udipsamments (217.907 $\mathrm{mg} \mathrm{L}^{-1}$ ). Flavonoids are a group of polyphenolic compounds in plants commonly found in vegetables, fruit, flowers, seeds, honey and propolis (Ahmad et al., 2015). Flavonoids are formed through the shikimat route and have antimicrobial and antioxidant properties.

The ability of flavonoid compounds as a secondary metabolite had been proven by several researchers. Arie et al. (2015) reported that cogongrass extract had an effect in suppressing the growth and sporing of Colletotrichum musae. According to Gusmarini et al. (2014), reeds extract could suppress the growth of C. musae, because cogongrass contains alkaloids, flavonoids, mannitol, malic acid, citric acid, coixol, arundoin, cylindrine, fernerol, simiarenol, anemone, esin, alkaline, saponins, tannins, and polyphenols.

Meanwhile, Kumar \& Pandey (2013) and Kalogianni et al. (2020) said that flavonoid compounds entered fungal cells through holes in the cell membrane that were formed because phenolic compounds have denatured cell membrane lipids. These protein compounds will be denatured by flavonoids through their hydrogen bonds. The ability of flavonoids to bind to proteins causes inhibition of cell wall formation, so that hyphal growth is also inhibited because the required cell wall composition is not fulfilled. Apart from being a structural component, protein also functions as a functional component, namely an enzyme. All metabolic reactions in cells are catalyzed by enzymes which are proteins. These metabolic reactions include important biosynthetic reactions and reactions that produce energy that result in cells being deprived of energy for growth (Maslanka et al., 2020). This results in inhibited hyphal elongation, so the growth of mycelium colonies will be smaller.

In Vivo Test. Based on the results of analysis of variance, there are significant differences in the variables of incubation period and disease intensity, infection rate, and AUDPC (Table 2).

Pathosystem Components. Symptoms of purple blotch began to appear at the $4^{\text {th }}$ week after planting. The fastest incubation period was found in the control but it was not significantly different from that of the cogongrass root extracts in Typic Udipsamments and Aeric Endoaqualfs, while the treatment of cogongrass root extracts of other soil types and fungicides was longer, and the longest was the cogongrass root extract of Aquertic Chromic Hapludalfs by $41.85 \%$ followed by Pachic Hapludolls at $40.25 \%$ compared to control (Table 2). Meanwhile, the incubation period for other soil types was not significantly different from the comparator propineb fungicide, and the application

Table 2. Effect of soil type where it was grown and the time of application of cogongrass root extracts on the development of onion purple blotch

\begin{tabular}{lccccc}
\hline $\begin{array}{c}\text { Types of soil where } \\
\text { cogongrass grow }\end{array}$ & $\begin{array}{c}\text { Application at } \\
\text { inoculation }\end{array}$ & $\begin{array}{c}\text { Incubation } \\
\text { period (DAI) }\end{array}$ & $\begin{array}{c}\text { Disease } \\
\text { intensity (\%) }\end{array}$ & $\begin{array}{c}\text { Infection rate } \\
\text { (unit per day) }\end{array}$ & $\begin{array}{c}\text { AUDPC } \\
(\% \text { day) }\end{array}$ \\
\hline Control & & $7.17 \mathrm{a}$ & $61.30 \mathrm{~h}$ & $0.1528 \mathrm{c}$ & $437.75 \mathrm{c}$ \\
Comparator (Propineb) & Before & $11.00 \mathrm{cde}$ & $28.05 \mathrm{def}$ & $0.0583 \mathrm{ab}$ & $203.28 \mathrm{ab}$ \\
& After & $9.67 \mathrm{cde}$ & $20.65 \mathrm{abc}$ & $0.0462 \mathrm{ab}$ & $169.44 \mathrm{ab}$ \\
Typic Udipsamments & Before & $8.33 \mathrm{abc}$ & $34.68 \mathrm{efg}$ & $0.0719 \mathrm{~b}$ & $229.64 \mathrm{~b}$ \\
\multirow{2}{*}{ Aeric Endoaqualfs } & After & $9.00 \mathrm{abc}$ & $35.45 \mathrm{efg}$ & $0.0711 \mathrm{~b}$ & $233.81 \mathrm{~b}$ \\
& Before & $7.33 \mathrm{ab}$ & $32.05 \mathrm{def}$ & $0.0691 \mathrm{ab}$ & $227.09 \mathrm{~b}$ \\
Typic Quartzipsamments & After & $9.00 \mathrm{ab}$ & $32.51 \mathrm{def}$ & $0.0689 \mathrm{ab}$ & $227.14 \mathrm{~b}$ \\
& Before & $9.00 \mathrm{bcd}$ & $29.59 \mathrm{def}$ & $0.0619 \mathrm{ab}$ & $212.51 \mathrm{ab}$ \\
Aquertic Chromic Hapludalfs & After & $11.00 \mathrm{bcd}$ & $26.93 \mathrm{def}$ & $0.0572 \mathrm{ab}$ & $211.22 \mathrm{ab}$ \\
& Before & $11.67 \mathrm{e}$ & $23.64 \mathrm{bcd}$ & $0.0517 \mathrm{ab}$ & $185.44 \mathrm{ab}$ \\
& After & $12.33 \mathrm{e}$ & $24.30 \mathrm{cde}$ & $0.0528 \mathrm{ab}$ & $189.63 \mathrm{ab}$ \\
Pachic Hapludolls & Before & $12.00 \mathrm{de}$ & $18.47 \mathrm{a}$ & $0.0380 \mathrm{a}$ & $141.70 \mathrm{a}$ \\
& After & $10.33 \mathrm{de}$ & $19.32 \mathrm{ab}$ & $0.0401 \mathrm{a}$ & $150.26 \mathrm{a}$ \\
\hline
\end{tabular}

The numbers followed by the same letter in the same column are not significantly different according to the DMRT level of $5 \%$. The data was transformed to $\sqrt{(x}+0.5)$. dai $=$ days after inoculation. 
before and after inoculation was not significantly different. This was because the chemical compound content of cogongrass root extract from each soil type was not the same. The results of the flavonoid content analysis showed that the roots of the cogongrass in Typic Udipsamments and Aeric Endoaqualfs were the lowest compared to other soil types. This was in accordance with the opinion of Kobayashi (2004) and Yang et al. (2018), that soil factors affected the production of plant secondary metabolite compounds.

In line with the fast incubation period, the highest disease intensity was found in shallots without treatment, which was significantly different from all treatments including comparator (Table 2). The smallest emphasis on purple blotch intensity was found in the cogongrass root extract of Pachic Hapludolls before inoculation of $69.87 \%$ compared to control. All treatments of cogongrass root extract did not differ from fungicide treatment, this meant that cogongrass root extract could replace the role of fungicides in overcoming onion purple blotch, with a suppression range between $42.17-69.87 \%$ compared to control.

This was consistent with the results of the in vitro test on the growth of fungal colonies, and was supported by the higher flavonoid content in the cogongrass root extract, especially from the Pachic Hapludolls soil type, which was $420.861 \mathrm{mg} \mathrm{L}^{-1}$. The high content of flavonoids contributes to the correlation and may have a role in reducing plant susceptibility by impacting resistance to disease-causing infections (McLay et al., 2020; Shah \& Smith, 2020). Furthermore, McLay et al. (2020) explained that UV-B-induced flavonoids could partially mediate the reduction in the phenotype of disease severity, which was negatively correlated with the amount of Bremia lactucae conidia in lettuce plants.

The incubation period data showed no significant difference in all treatments of cogongrass root extract, while the disease intensity data were significantly different. This was presumably due to the insufficient dose of cogongrass root extract or the slow mechanism of flavonoids in overcoming symptoms. Meanwhile, when these compounds begin to be absorbed by plants, activity in the face of pathogen attacks begins to appear. This condition was in accordance with the statement of Shah \& Smith (2020), that flavonoids were secondary metabolites and biostimulants; which played a key role in plant growth by impacting resistance to certain biotic and abiotic stresses.

Time of treatment application had no significant effect between before and after inoculation. In almost all treatments, the application time before inoculation tended to be higher than that applied after inoculation (Table 2). It was suspected that the treatment applied before the inoculation of plant pathogens could serve as a preventive measure. This was in accordance with the opinion of Khalid et al. (2019), that the application of flavonoids, in particular, was related to the protection of plants from pathogen attack and had a very important role in plant resistance to pathogens.

Meanwhile, the intensity of the disease tended to increase in line with the increasing age of the shallot plants (Figure 1). However, the incidence of disease progression was much higher in the untreated compared to treated plants. This was in accordance with the statement of Mierziak et al. (2014) stated that flavonoid compounds were transported to the site of infection and cause hypersensitivity reactions, thus inhibiting disease progression.

The highest infection rate was found in the control and the lowest in the root extract of cogongrass Pachic Hapludolls application before inoculation (Table 4). The development of the infection rate during five observations could be seen in Figure 2. The cogongrass root extract was able to compensate for propineb in suppressing the rate of infection. The application of Pachic Hapludolls cogongrass root extract before inoculation was able to slow down the infection rate by $75.13 \%$ compared to control. However, overall, the mean infection rate was less than 0.5 per unit per day. According to Van Der Plank (1963), the infection rate value could be defined as whether the pathogen was aggressive, the variety was susceptible or resistant, and whether the environment was favorable or not for the development of the disease. Furthermore, it said that if the value of $r$ was greater than 0.5 units per day, it meant that the pathogen was aggressive, the varieties were susceptible and the weather was favorable.

The slow growth rate of infection in the treatment based on the results of the 5\% DMRT did not significantly differ between the propineb fungicide and all cogongrass root extracts. There was no significant difference between the applications before and after inoculation. This condition was in line with the incubation period and the intensity of the disease above. This was supported by the important role of flavonoids contained in cogongrass root extracts, which play a role in protecting plants against the attack of biotic and abiotic pathogens (McLay et al., 2020; Shah \& Smith, 2020).

Meanwhile, the control treatment had a higher AUDPC value than the treatment, which was in line with the incubation period, disease intensity, and infection rate (Table 2). The treatment of cogongrass Pachic 


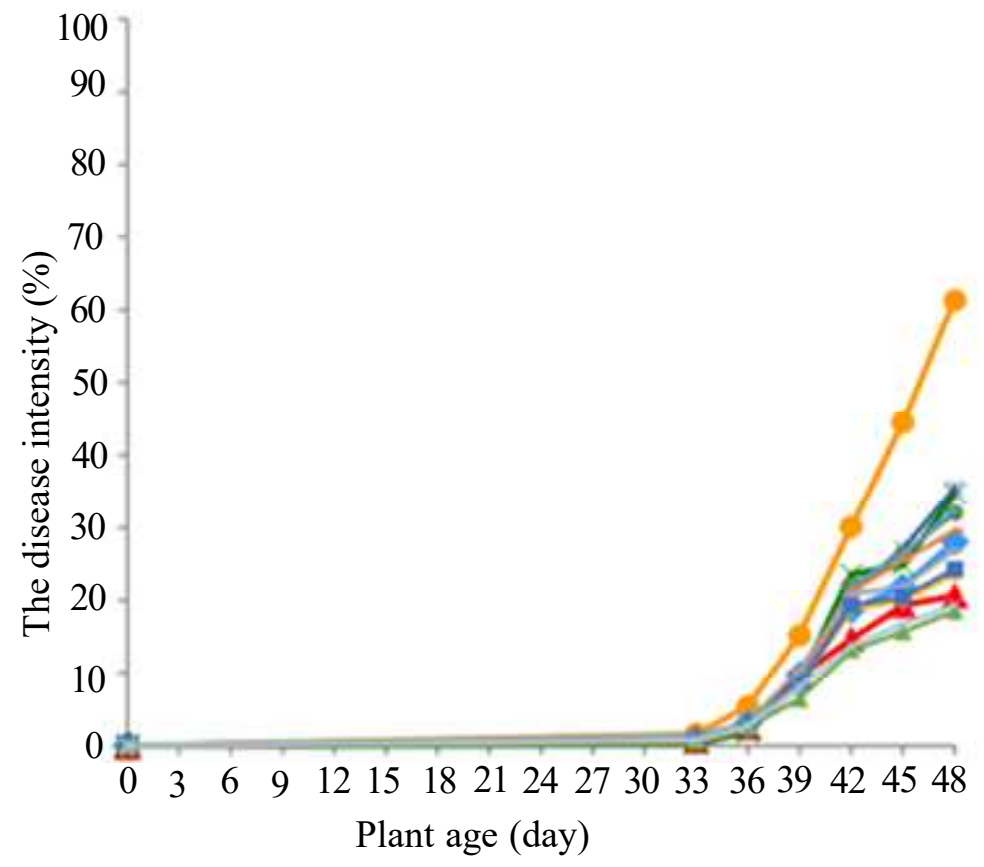

$\rightarrow$ Control

$\rightarrow$ Propineb-S1

-Propineb-S2

-Typic Udipsamments-S1

— Typic Udipsamment-S2

$\rightarrow-$ Aeric Endoaqualfs-S1

- Aeric Endoaqualfs-S2

- Typic Quartzipsamments-S1

- Typic Quartzipsamments-S2

$\rightarrow$ Aquertic Chromic Hapludalfs-S1

- - Aquertic Chromic Hapludalfs-S2

-Pachic Hapludolls-S1

- Pachic Hapludolls-S2

Figure 1. Development of purple blotch due to cogongrass root extract treatment from types of soil. Information: $\mathrm{S} 1=$ before inoculation and $\mathrm{S} 2=$ after inoculation .

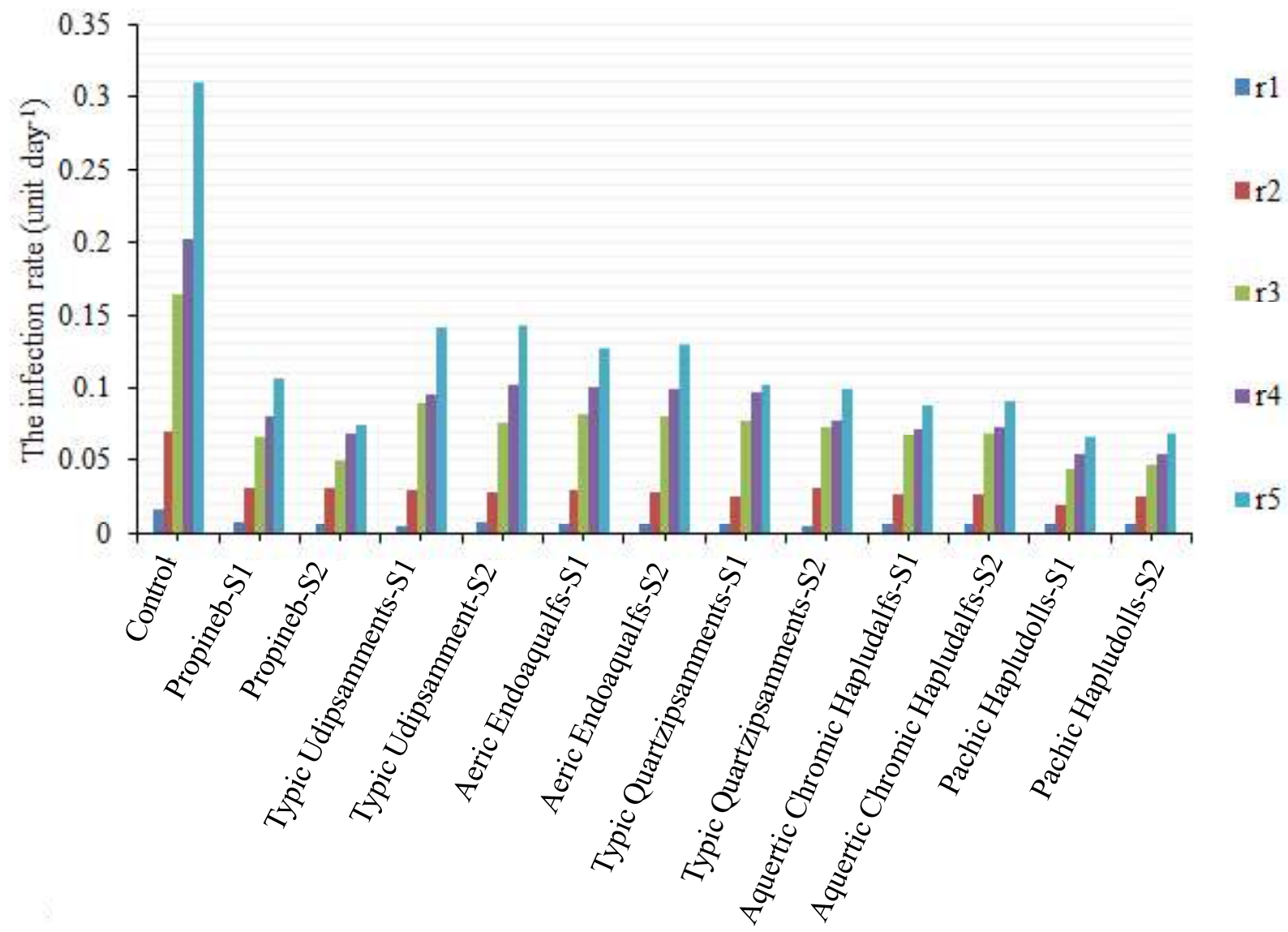

Figure 2. Development of purple blotch infection rate due to ogongrass root extract treatment from types of soil. Information: $\mathrm{S} 1=$ before inoculation; $\mathrm{S} 2=$ after inoculation; $\mathrm{r}=$ infection rate; $1,2,3,4,5=$ observation times. 
Haludolls root extract before inoculation showed the highest AUDPC suppressor value of $67.63 \%$ compared to control. This was consistent with the suppression of disease intensity and infection rate. The AUDPC value in the cogongrass root extract was not significantly different from the propineb, even the AUDPC value in the propineb fungicide treatment tended to be higher when compared to the treatment of cogongrass root extract Pachic Hapludolls and Aquertic Chromic Hapludalfs.

The application of propineb before inoculation caused shallot plants to be relatively more susceptible to pathogens. This was thought to be the nature of the contact propineb fungicide, so that when applied before inoculation it can wash off or evaporate. In accordance with the statement of Majeed et al. (2014) stated that systemic fungicides were more effective at controlling disease severity and disease progression than contact fungicides. This was because of the non-absorption capacity into host tissue, contact fungicides were only effective when applied at shorter intervals (Carmona et al., 2020). AUDPC chart was shown in Figure 3.

AUDPC is a parameter to measure the progression of disease severity over a certain time (Apriyadi et al., 2013). The higher the AUDPC value, the lower the resistance level or the percentage of inhibition in the treatment (Gunaeni, 2015). According to Nuryani et al. (2011), if the AUDPC number was lower, the treatment would be more effective in controlling the pathogen, and conversely, the higher the
AUDPC number, the treatment will have no effect on pathogen infection. Based on the data above (Table 2), it appeared that the treatment of cogongrass root extract was able to reduce the AUDPC value. Thus, there was a chance that cogongrass root extract could be used to control purple blotch on shallots.

Based on the results, it turned out that cogongrass root extract could compensate for the ability of the propineb fungicide in suppressing the development of purple blotch on shallots and impacting resistance of shallots. This was reinforced by the results of the analysis of the total phenol of shallots, namely propineb fungicide (12.97 $\left.\mathrm{mg} \mathrm{g}^{-1}\right)$, and the cogongrass root extract of Typic Udipsamments (11.51 $\left.\mathrm{mg} \mathrm{g}^{-1}\right)$, of Aeric Endoaqualfs (12.22 $\mathrm{mg} \mathrm{g}^{-1}$ ), of Typic Quartzipsamments (12.84 $\mathrm{mg} \mathrm{g}^{-1}$ ), of Aquertic Chromic Hapludalfs (11.66 $\left.\mathrm{mg} \mathrm{g}^{-1}\right)$, and of Pachic Hapluderts (13.84 $\mathrm{mg} \mathrm{g}^{-1}$ ).

Growth Components. The range of mean plant height, number of leaves, leaf area, chlorophyll content, and number of tillers showed no significant difference between treatment and control (Table 3 ).

Vegetative growth of plants is more influenced by the availability of nutrients, which function to maintain the survival of a plant. These nutrients include N, P, and $\mathrm{K}$. The availability of nutrients needed by plants results in a better vegetative plant growth and will accelerate the generation of the plant's generative phase (Isda et al., 2013).

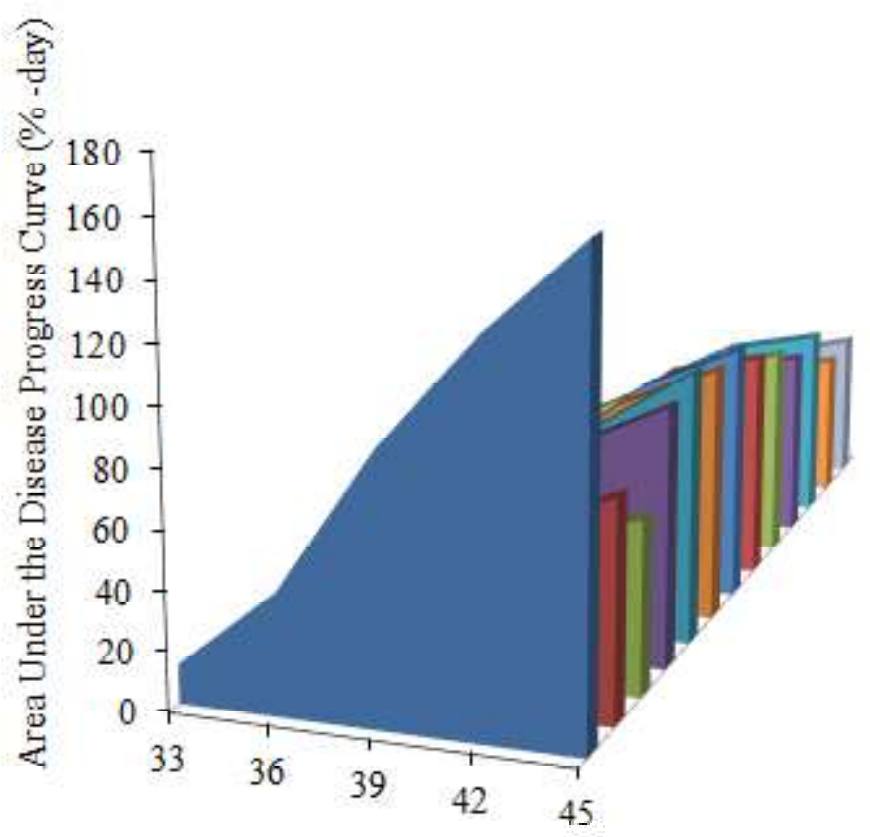

\author{
- Control \\ Propineb-S1 \\ Propineb-S2 \\ - Typic Udipsamments-S1 \\ - Typic Udipsamment-S2 \\ Aeric Endoaqualfs-S1 \\ -Aeric Endoaqualfs-S2 \\ Typic Quartzipsamments-S1 \\ Typic Quartzipsamments-S2 \\ Aquertic Chromic Hapludalfs-S1 \\ - Aquertic Chromic Hapludalfs-S2 \\ - Pachic Hapludolls-S1 \\ 'Pachic Hapludolls-S2
}

Figure 3. Differences in AUDPC values of onion purple blotch due to cogongrass root extract treatment from types of soil. Information: $\mathrm{S} 1=$ before inoculation and $\mathrm{S} 2=$ after inoculation. 
Yield Components. All treatments had no significant effect on the number of tubers planted (Table 4). This was thought to be related to the growth component which was not significantly different. According to Sumarni et al. (2012), the number of tillers or the number of tubers was determined more by genetic factors than environmental factors including fertilization. This was also stated by Sekara et al. (2017), that the number of shallot tillers was a plant genetic trait that cannot be easily changed by external factors.

The treatment of cogongrass root extract Pachic Hapludolls before inoculation was able to increase the highest plant fresh weight per plant by $42.7 \%$ compared to the control (Table 4). In addition, the application of Pachic Hapludolls cogongrass root extract before inoculation increased the plant dry weight per plant and the highest tuber dry weight per plant by 49.6 and $51.92 \%$, respectively, compared to the control. There was no significant difference between propineb fungicide treatment and all cogongrass root extract treatments. This was consistent with the data on the low pathosystem components (Table 2).

In line with Table 4, the treatment of cogongrass root extract Pachic Hapludolls before inoculation was able to increase the plant fresh weight per plot, plant dry weight per plot, and the highest tuber dry weight per plot, respectively $66.75,72.29$, and $73.53 \%$ compared to control (Table 5). Propineb fungicide treatment was not significantly different from all treatments of cogongrass root extract. However, among the cogongrass root extract treatments, there were differences in tuber dry weight per plot. The cogongrass root extract of Pachic Hapludolls was different from that of Typic Quartzipsamments, Aeric Endoaqualfs, and Typic Udipsamments. When compared to the control, treatment of cogongrass root extract Pachic Hapludolls before inoculation can increase the yield of dry tubers per hectare as $73.53 \%$.

The effect of the application of cogongrass root extract on yield components because the cogongrass root extract contains nutrients needed by shallot plants. Hagan et al. (2013) and Isda et al. (2013) added that in addition to producing phenolic compounds, cogongrass also produces nutrients which can be used as growth promoters. Cogongrass roots contain heavy metal compounds such as iron (Paz-Alberto et al., 2007; de la Fuente et al., 2017). The function of iron (Fe) is to play a role in the formation of chlorophyll, $\mathrm{Cu}$ is a constituent of enzymes, the formation of chlorophyll, and the metabolism of carbohydrates and proteins (Printz et al., 2016).

Table 3. Effect of soil type where cogongrass grows and application time on plant height, number of leaves, leaf area, leaf chlorophyll, and number of tillers

\begin{tabular}{llccccc}
\hline $\begin{array}{c}\text { Types of soil where } \\
\text { cogongrass grow }\end{array}$ & $\begin{array}{c}\text { Application } \\
\text { at inoculation }\end{array}$ & $\begin{array}{c}\text { Plant height } \\
(\mathrm{cm})\end{array}$ & $\begin{array}{c}\text { Number of } \\
\text { leaves }\end{array}$ & $\begin{array}{c}\text { Leaf area } \\
\left(\mathrm{cm}^{2}\right)\end{array}$ & $\begin{array}{c}\text { Leaf } \\
\text { Chlorophyll } \\
(\text { CCI })\end{array}$ & $\begin{array}{c}\text { Number } \\
\text { of tillers }\end{array}$ \\
\hline Control & & $34.42 \mathrm{a}$ & $20.57 \mathrm{a}$ & $8.05 \mathrm{a}$ & $4.98 \mathrm{a}$ & $5.33 \mathrm{a}$ \\
Comparator (propineb) & Before & $35.89 \mathrm{a}$ & $22.00 \mathrm{a}$ & $6.75 \mathrm{a}$ & $5.18 \mathrm{a}$ & $5.00 \mathrm{a}$ \\
& After & $36.05 \mathrm{a}$ & $23.67 \mathrm{a}$ & $7.18 \mathrm{a}$ & $4.93 \mathrm{a}$ & $5.33 \mathrm{a}$ \\
Typic Udipsamments & Before & $35.55 \mathrm{a}$ & $23.00 \mathrm{a}$ & $8.74 \mathrm{a}$ & $6.57 \mathrm{a}$ & $5.67 \mathrm{a}$ \\
& After & $37.85 \mathrm{a}$ & $22.67 \mathrm{a}$ & $9.08 \mathrm{a}$ & $3.77 \mathrm{a}$ & $5.67 \mathrm{a}$ \\
Aeric Endoaqualfs & Before & $38.23 \mathrm{a}$ & $23.33 \mathrm{a}$ & $7.68 \mathrm{a}$ & $5.28 \mathrm{a}$ & $4.67 \mathrm{a}$ \\
& After & $38.20 \mathrm{a}$ & $22.00 \mathrm{a}$ & $8.14 \mathrm{a}$ & $7.25 \mathrm{a}$ & $5.00 \mathrm{a}$ \\
Typic Quartzipsamments & Before & $38.77 \mathrm{a}$ & $22.67 \mathrm{a}$ & $8.90 \mathrm{a}$ & $5.27 \mathrm{a}$ & $5.00 \mathrm{a}$ \\
& After & $38.17 \mathrm{a}$ & $21.67 \mathrm{a}$ & $8.10 \mathrm{a}$ & $6.17 \mathrm{a}$ & $5.00 \mathrm{a}$ \\
Aquertic Chromic Hapludalfs & Before & $37.10 \mathrm{a}$ & $22.67 \mathrm{a}$ & $7.20 \mathrm{a}$ & $4.38 \mathrm{a}$ & $5.00 \mathrm{a}$ \\
& After & $36.35 \mathrm{a}$ & $21.00 \mathrm{a}$ & $8.10 \mathrm{a}$ & $3.53 \mathrm{a}$ & $4.67 \mathrm{a}$ \\
Pachic Hapludolls & Before & $38.27 \mathrm{a}$ & $22.67 \mathrm{a}$ & $8.32 \mathrm{a}$ & $6.16 \mathrm{a}$ & $5.00 \mathrm{a}$ \\
& After & $36.50 \mathrm{a}$ & $22.67 \mathrm{a}$ & $6.66 \mathrm{a}$ & $9.87 \mathrm{a}$ & $5.00 \mathrm{a}$ \\
\hline
\end{tabular}

The numbers followed by the same letter in the same column are not significantly different according to the DMRT level of 5\%. CCI $=$ Chlorophyll Content Index. 
Table 4. Effect of soil type where it is grown and application time to the number of tubers, plant fresh and dry weight, and tuber dry weight per plant

\begin{tabular}{llcccc}
\hline $\begin{array}{c}\text { Types of soil where } \\
\text { cogongrass grow }\end{array}$ & $\begin{array}{c}\text { Aplication } \\
\text { at inoculation }\end{array}$ & $\begin{array}{c}\text { Number of } \\
\text { tubers }\end{array}$ & $\begin{array}{c}\text { Plant fresh } \\
\text { weight plant } \\
(\mathrm{g})\end{array}$ & $\begin{array}{c}\text { Plant dry } \\
\text { weight plant } \\
(\mathrm{g})\end{array}$ & $\begin{array}{c}\text { Tuber dry } \\
\text { weight plant } \\
(\mathrm{g})\end{array}$ \\
\hline Control & & $4.50 \mathrm{a}$ & $17.58 \mathrm{a}$ & $12.08 \mathrm{a}$ & $10.83 \mathrm{a}$ \\
Comparator (propineb) & Before & $5.67 \mathrm{a}$ & $25.27 \mathrm{bc}$ & $20.63 \mathrm{~cd}$ & $17.67 \mathrm{bc}$ \\
& After & $5.67 \mathrm{a}$ & $29.90 \mathrm{bc}$ & $23.10 \mathrm{~cd}$ & $21.70 \mathrm{bc}$ \\
Typic Udipsamments & Before & $5.33 \mathrm{a}$ & $26.06 \mathrm{bc}$ & $19.74 \mathrm{bc}$ & $18.04 \mathrm{~b}$ \\
& After & $5.00 \mathrm{a}$ & $24.47 \mathrm{bc}$ & $16.80 \mathrm{bc}$ & $15.43 \mathrm{~b}$ \\
Aeric Endoaqualfs & Before & $5.00 \mathrm{a}$ & $25.57 \mathrm{bc}$ & $19.42 \mathrm{bcd}$ & $18.23 \mathrm{bc}$ \\
& After & $5.33 \mathrm{a}$ & $29.83 \mathrm{bc}$ & $20.72 \mathrm{bcd}$ & $19.33 \mathrm{bc}$ \\
Typic Quartzipsamments & Before & $5.00 \mathrm{a}$ & $25.84 \mathrm{~b}$ & $19.82 \mathrm{~b}$ & $18.58 \mathrm{~b}$ \\
& After & $5.67 \mathrm{a}$ & $21.30 \mathrm{~b}$ & $14.14 \mathrm{~b}$ & $12.60 \mathrm{~b}$ \\
Aquertic Chromic Hapludalfs & Before & $4.67 \mathrm{a}$ & $27.93 \mathrm{bc}$ & $19.03 \mathrm{bc}$ & $17.90 \mathrm{~b}$ \\
& After & $4.67 \mathrm{a}$ & $24.77 \mathrm{bc}$ & $18.47 \mathrm{bc}$ & $17.32 \mathrm{~b}$ \\
Pachic Hapludolls & Before & $4.33 \mathrm{a}$ & $30.68 \mathrm{c}$ & $23.97 \mathrm{~d}$ & $22.54 \mathrm{c}$ \\
& After & $5.67 \mathrm{a}$ & $28.73 \mathrm{c}$ & $24.13 \mathrm{~d}$ & $23.07 \mathrm{c}$ \\
\hline
\end{tabular}

The numbers followed by the same letter in the same column are not significantly different according to the DMRT level of $5 \%$.

Table 5. Effect of soil type where it is grown and application time on plant fresh weight, plant dry weight, and tuber dry weight per plot

\begin{tabular}{llccc}
\hline $\begin{array}{c}\text { Types of soil where } \\
\text { cogongrass grow }\end{array}$ & $\begin{array}{c}\text { Application at } \\
\text { inoculation }\end{array}$ & $\begin{array}{c}\text { Plant fresh } \\
\text { weight per plot } \\
(\mathrm{g})\end{array}$ & $\begin{array}{c}\text { Plant dry } \\
\text { weight per plot } \\
(\mathrm{g})\end{array}$ & $\begin{array}{c}\text { Tuber dry } \\
\text { weight per plot } \\
(\mathrm{g})\end{array}$ \\
\hline Control & & $224.33 \mathrm{a}$ & $147.33 \mathrm{a}$ & $130.75 \mathrm{a}$ \\
Comparator (propineb) & Before & $407.00 \mathrm{bc}$ & $323.33 \mathrm{bc}$ & $283.00 \mathrm{bc}$ \\
& After & $619.00 \mathrm{bc}$ & $489.00 \mathrm{bc}$ & $443.67 \mathrm{bc}$ \\
Typic Udipsamments & Before & $403.33 \mathrm{~b}$ & $317.67 \mathrm{~b}$ & $279.33 \mathrm{~b}$ \\
& After & $414.00 \mathrm{~b}$ & $328.00 \mathrm{~b}$ & $294.00 \mathrm{~b}$ \\
Aeric Endoaqualfs & Before & $446.33 \mathrm{~b}$ & $334.67 \mathrm{~b}$ & $305.67 \mathrm{~b}$ \\
& After & $513.00 \mathrm{~b}$ & $407.33 \mathrm{~b}$ & $315.00 \mathrm{~b}$ \\
Typic Quartzipsamments & Before & $422.33 \mathrm{~b}$ & $333.67 \mathrm{~b}$ & $305.00 \mathrm{~b}$ \\
& After & $326.00 \mathrm{~b}$ & $257.33 \mathrm{~b}$ & $215.67 \mathrm{~b}$ \\
Aquertic Chromic Hapludalfs & Before & $527.00 \mathrm{bc}$ & $416.33 \mathrm{bc}$ & $362.00 \mathrm{bc}$ \\
& After & $507.33 \mathrm{bc}$ & $396.33 \mathrm{bc}$ & $338.00 \mathrm{bc}$ \\
Pachic Hapludolls & Before & $674.67 \mathrm{c}$ & $531.67 \mathrm{c}$ & $494.00 \mathrm{c}$ \\
& After & $598.00 \mathrm{c}$ & $472.67 \mathrm{c}$ & $457.00 \mathrm{c}$ \\
\hline
\end{tabular}

The numbers followed by the same letter in the same column are not significantly different according to the DMRT level of $5 \%$. 


\section{CONCLUSION}

Cogongrass root extract was able to inhibit the growth of $A$. porri fungi in vitro. The treatment of Pachic Hapludolls $60 \%$ cogongrass root extract was the best extract concentration in the in vitro test. The treatment of Pachic Hapludolls cogongrass root extract before inoculation had a significant effect on the highest pathosystem components by being able to delay the appearance of purple blotch by up to $41.85 \%$, reducing disease intensity by $69.87 \%$, slowing the infection rate by up to $75.13 \%$, and reducing the AUDPC value up to $67.63 \%$ compared to control. The treatment of Pachic Hapludolls cogongrass root extract before inoculation increased plant fresh and dry weight per plant, tuber weight per plant, plant fresh weight per plot, plant dry weight per plot, and the highest tuber dry weight per plot, respectively, as 42.7, 49.6, 51.92, 66.75, 72.29, and $73.53 \%$ compared to control.

\section{ACKNOWLEDGMENTS}

We are grateful to Panji Pamekas, Tamrin Khamidi, Abdul Aziz, Yulian Tri Affandi, and Kuswadi for their assistance.

\section{REFERENCES}

Abdel-Hafez SII, Abo-Elyousr KAM, \& Abdel-Rahim IR. 2013. Effect of certain plant extracts to control purple blotch disease of onion plants (Allium cepa L.). J. Plant Physiol. Pathol. 1(4): 4.

Ahmad AR, Dahlia AA, \& Kosman R. 2014. Standardization of simplisia and methanolic extract of cemba (Acacia rugata (Lam.) Fawc. Rendle) leaves endemic plant from Massenrenpulu regency of Enrekang. World J. Pharm. Sci. 2(12): 1808-1812.

Ahmad A, Kaleem M, Ahmed Z, \& Shafiq H. 2015. Therapeutic potential of flavonoids and their mechanism of action against microbial and viral infections-A review. Food Res. Int. 77(2): 221235 .

Apriyadi AR, Wahyuni WS, \& Supartini V. 2013. Pengendalian penyakit patik (Cercospora nicotianae) pada tembakau $\mathrm{Na}$ Oogst secara invivo dengan ekstrak daun gulma kipahit (Tithonia diversifolia). Berkala Ilmiah Pertanian. 1(2): 30-32.
Arie IZ, Prasetyo J, \& Efri. 2015. Pengaruh ekstrak alang-alang, babadotan dan teki terhadap penyakit antraknosa pada buah pisang kultivar Cavendish. J. Agrotek Tropika. 3(2): 251-256.

Bekker TF, Kaiser C, Merwe Rvd, \& Labuschagne N. 2006. In-vitro inhibition of mycelial growth of several phytopathogenic fungi by soluble potassium silicate. S. Afr. J. Plant Soil. 23(3): $169-172$

Blainski A, Lopes GC, \& de Mello JCP. 2013. Application and analysis of the Folin Ciocalteu method for the determination of the total phenolic content from Limonium brasiliense L. Molecules. 18(6): 6852-6865.

Bryson CT, Krutz LJ, Ervin GN, Reddy KN, \& Byrd JD. 2010. Ecotype variability and edaphic characteristics for cogongrass (Imperata cylindrica) populations in Mississippi. Invasive Plant Sci. Manag. 3(3): 199-207.

Carmona M, Sautua F, Pérez-Hérnandez O, \& Reis EM. 2020. Role of fungicide applications on the integrated management of wheat stripe rust. Front Plant Sci. 11: 733.

Chandra S, Khan S, Avula B, Lata H, Yang MH, Elsohly MA, \& Khan IA. 2014. Assessment of total phenolic and flavonoid content, antioxidant properties, and yield of aeroponically and conventionally grown leafy vegetables and fruit crops: a comparative study. Evid. Based Complement. Alternat. Med. 2014: 253875.

Dar AA, Sharma S, Mahajan R, Mushtaq M, Salathia A, Ahamad S, \& Sharma JP. 2020. Overview of purple blotch disease and understanding its management through chemical, biological and genetic approaches. J. Integr. Agric. 19(12): 3013-3024.

de la Fuente V, Rufo L, Rodríguez N, Franco A, \& Amils R. 2017. Comparison of iron localization in wild plants and hydroponic cultures of Imperata cylindrica (L.) P. Beauv. Plant Soil. 418(1-2): $25-35$.

Gunaeni N. 2015. Pengendalian hama dan penyakit secara fisik dan mekanik pada produksi bawang daun (Allium fistolosum L.). Agrin. 19(1): 3751. 
Gurjar MS, Ali S, Akhtar M, \& Singh KS. 2012. Efficacy of plant extracts in plant disease management. Agric. Sci. 3(3): 425-433.

Gusmarini M, Dirmawati SR, Nurdin M, \& Akin HM. 2014. Pengaruh beberapa jenis ekstrak tumbuhan terhadap penyakit antraknosa pada tanaman cabai besar (Capsicum annuum L.) di lapangan. $J$. Agrotek Tropika. 2(2): 197-201.

Hagan D, Jose S, \& Lin CH. 2013. Allelopathic exudates of cogongrass (Imperata cylindrica): implications for the performance of native pine savanna plant species in the Southeastern US. $J$. Chem. Ecol. 39(2): 312-322.

Idris N \& Nurmasnyah. 2015. Efektivitas ekstrak etanol beberapa tanaman obat sebagai bahan baku fungisida nabati untuk mengendalikan Colletotrichum gloeosporiodes. Bul. Littro. 26(2): 117-124.

Isda MN, Lestari W, \& Agriani D. 2013. Optimasi konsentrasi ekstrak alang-alang (Imperata cylindrical L.) untuk memacu pertumbuhan dan produksi jagung manis (Zea mays saccharata Sturt). Al-Kauniyah Jurnal Biologi. 6(1): 4752.

Jhala P, Mali BL, \& Meena MK. 2017. Effective management of purple blotch of onion caused by Alternaria porri (Ellis) through host resistance, fungicides and botanicals. Int. J. Curr. Microbiol. App. Sci. 6(5): 1737-1745.

Kalogianni AI, Lazou T, Bossis I, \& Gelasakis AI. 2020. Natural phenolic compounds for the control of oxidation, bacterial spoilage, and foodborne pathogens in meat. Foods. 9(6): 794.

Kareem MA, Murthy KVMK, Nadaf HA, \& Waseem MA. 2012. Effect of temperature, relative humidity and light on lesion length due to Alternaria porri in onion. Asian J. Environ. Sci. 7(1): 47-49.

Khalid M, Saeed-ur-Rahmana, Bilal M, \& Huang DF. 2019. Role of flavonoids in plant interactions with the environment and against human pathogens — a review. J. Integr. Agric. 18(1): 211-230.

Kobayashi K. 2004. Factors affecting phytotoxic activity of allelochemicals in soil. Weed Biol. Manag. 4(1): 1-7.
Kumar S \& Pandey AK. 2013. Chemistry and biological activities of flavonoids: an overview. Sci. World J. 2013: 162750 .

Ling ASC, Kamil MJA, Chong KP, \& Ho CM. 2017. Assessing the cocoa genotypes for resistance to black pod using the area under the diseaseprogress curve (AUDPC). Bulg. J. Agric. Sci. 23(6): 972-979.

Liu H, Taylor Jr TH, Pettus K, Johnson S, Papp JR, \& Trees D. 2016. Comparing the disk-diffusion and agar dilution tests for Neisseria gonorrhoeae antimicrobial susceptibility testing. Antimicrob. Resist. Infect. Control 5: 46.

Maftuchah \& Idiyah S. 1995. Analisa Pertumbuhan Tanaman. Universitas Muhamadiyah Malang. Malang.

Majeed A, Ahmad H, Ali MA, \& Khan H. 2014. Effect of systemic and contact fungicides on late blight disease and tuber yield of potato. J. Agric. Sci. Technol. 10(1): 209-217.

Mallik AU. 2000. Challenges and opportunities in allelopathy research: a brief overview. J. Chem. Ecol. 26: 2007-2009.

Marlitasari E, Sulistyowati L, \& Kusuma RR. 2016. Hubungan ketebalan lapisan epidermis daun terhadap infeksi jamur Alternaria porri penyebab penyakit bercak ungu pada empat varietas bawang merah. J. HPT. 4(1): 8-16.

Maslanka R, Zadrag-Tecza R, \& Kwolek-Mirek M. 2020. Linkage between carbon metabolism, redox status and cellular physiology in the yeast Saccharomyces cerevisiae devoid of SOD1 or SOD2 gene. Genes 11(7): 780.

McLay ER, Pontaroli AC, \& Wargent JJ. 2020. UV-B induced flavonoids contribute to reduced biotrophic disease susceptibility in lettuce seedlings. Front. Plant Sci. 11: 594681.

Mierziak J, Kostyn K, \& Kulma A. 2014. Flavonoids as important molecules of plant interactions with the environment. Molecules. 19(10): 16240-16265.

Muchtaromah B, Ahmad M, Romaidi, Nazilah LA, \& Naja NA. 2018. Antibacterial activity of water and ethanol extract of Allium sativum, Curcuma mangga, and Acorus calamus combination. $J$. Biol. Res. 24(1): 8-15. 
Nuryani W, Yusuf ES, Djatnika I, Hanudin, \& Marwoto B. 2011. Pengendalian penyakit layu fusarium pada subang gladiol dengan pengasapan dan biopestisida. J. Hort. 21(1): 40-50.

Paz-Alberto AM, Sigua GC, Baui BG, \& Prudente JA. 2007. Phytoextraction of lead-contaminated soil using vetivergrass (Vetiveria zizanioides L.), cogongrass (Imperata cylindrica L.) and carabaograss (Paspalum conjugatum L.). Environ. Sci. Pollut. Res. 14(7): 498-504.

Printz B, Lutts S, Hausman JF, \& Sergeant K. 2016. Copper trafficking in plants and its implication on cell wall dynamics. Front. Plant Sci. 7: 601.

Rai B \& Singh DB. 1980. Antagonistic activity of some leaf survafe microfungi against Alternaria brassicae and Drechslera gramineae. Trans. Brit. Mycol. Soc. 75(3): 365-369.

Sari MP, Hadisutrisno B, \& Suryanti. 2016. Penekanan perkembangan penyakit bercak ungu pada bawang merah oleh cendawan mikoriza arbuskula. J. Fitopatologi Indonesia. 12(5): 159-167.

Sekara A, Pokluda R, Del Vacchio L, Somma S, \& Caruso G. 2017. Interactions among genotype, environment and agronomic practices on production and quality of storage onion (Allium cepa L.) - a review. Hort. Sci. (Prague). 44: $21-42$.

Seniwaty, Raihanah, Nugraheni IK, \& Umaningrum D. 2009. Skrining fitokimia dari alang-alang (Imperata cylindrica L. Beauv.) dan lidah ular (Hedyotis corymbosa L. Lamk). Sains dan Terapan Kimia. 3(2):124-133.

Setiawati W, Gunaeni N, Subhan, \& Muharam A. 2011. Pengaruh pemupukan dan tumpangsari antara tomat dan kubis terhadap populasi Bemisia tabaci dan insiden penyakit virus kuning pada tanaman tomat. J. Hort. 21(2): 135-144.
Shah A \& Smith DL. 2020. Flavonoids in agriculture: chemistry and roles in, biotic and abiotic stress responses, and microbial associations. Agronomy 10(8): 1209.

Sumarni N, Rosliani R, \& Basuki RS. 2012. Respons pertumbuhan, hasil umbi, dan serapan hara NPK tanaman bawang merah terhadap berbagai dosis pemupukan NPK pada tanah alluvial. J. Hort. 22(4): 366-375.

Supriyanto, Purwanto, Poromarto SH, \& Supyani. 2020. Evaluation of in vitro antagonistic activity of fungi from peatlands against Ganoderma species under acidic condition. Biodiversitas 21(7): 2935-2945.

Suryanto D, Irawati N, \& Munir E. 2011. Isolation and characterization of chitinolytic bacteria and their potential to inhibit plant pathogenic fungi. Microbiol. Indones. 5(3): 144-148.

Taherdoost H. 2016. Sampling methods in research methodology; how to choose a sampling technique for research. Int. J. Acad. Res. Manag. 5(2): $18-27$.

Tombe M, Pangeran D, \& Haryani TS. 2012. Keefektifan formula minyak cengkeh dan serai wangi terhadap Fusarium oxysporum f.sp. vanillae penyebab busuk batang vanili. Jurnal Littri. 18(4): 143-150.

Van Der Plank JE. 1963. Plant Diseases: Epidemics and Control. Academic Press. New York.

Yang L, Wen KS, Ruan X, Zhao YX, Wei F, \& Wang Q. 2018. Response of plant secondary metabolites to environmental factors. Molecules. 23(4): 762.

Zhang QW, Lin LG, \& Ye WC. 2018. Techniques for extraction and isolation of natural products: a comprehensive review. Chin. Med. 13: 20. 